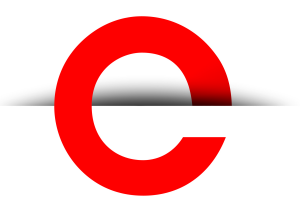

U T S

e PRES S
PORTAL Journal of Multidisciplinary International Studies

Vol. 17, No. 1/2

Jan 2021

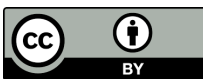

(c) 2021 by the author(s). This is an Open Access article distributed under the terms of the Creative Commons Attribution 4.0 International (CC BY 4.0) License (https:// creativecommons.org/ licenses/by/4.0/), allowing third parties to copy and redistribute the material in any medium or format and to remix, transform, and build upon the material for any purpose, even commercially, provided the original work is properly cited and states its license.

Citation: Bao, H. 2021. Queer disidentification: Or How to Cook Chinese Noodles in a Global Pandemic? PORTAL Journal of Multidisciplinary International Studies, 17:1/2, 85-90. http://dx.doi. org/10.5130/pjmis.v17i12.7299

ISSN 1449-2490 | Published by UTS ePRESS | http://epress. lib.uts.edu.au/ojs/index.php/ portal
ESSAY

\section{Queer Disidentification: Or How to Cook Chinese Noodles in a Global Pandemic?}

\author{
Hongwei Bao \\ Corresponding author: Hongwei Bao, Associate Professor in Media Studies, School of Cultures, \\ Languages and Area Studies, Faculty of Arts, University of Nottingham, University Park, \\ Nottingham, NG7 2RD, United Kingdom. Hongwei.Baodnottingham.ac.uk
}

DOI: http://dx.doi.org/10.5130/pjmis.v17i1-2.7299

Article History: Received 29/06/2020; Revised 05/11/2020; Accepted 05/11/2020;

Published 28/01/2021

\begin{abstract}
In this article, I offer a critical analysis of a video artwork titled Lerne Deutsch in meiner Küche (Learn German in My Kitchen) (2020), created by Berlin-based queer filmmaker Popo Fan. By focusing on Fan's negotiation of racial, ethnic, and cultural identities in the video, I argue that Fan's artwork offers a way to reimagine identities away from the identity politics that are widely circulated in the current pandemic discourse. My analysis draws on José Esteban Muñoz's (1999) notion of 'disidentification,' which describes minority subjects' complex processes of identification-in particular, instances of identifying partially, conditionally and contingently-with dominant identities, discourses and ideologies. In doing so, I unravel the intricate politics of identity in the current global pandemic and highlight the role of queer disidentification as an important critical intervention in the current political debate about the COVID-19 pandemic.
\end{abstract}

\section{Keywords}

\section{Queer; China; COVID-19; Activism; Popo Fan; Racism}

In an online research seminar titled 'Intimacies in Asia in a Time of Pandemics' (GCS Sydney 2020), Hans Tao-Ming Huang, a queer studies scholar from National Central University, Taiwan, compares the geopolitics in the current COVID-19 pandemic to a 'new Cold War.'This war is characterised by an intense political and ideological antagonism between communist China and the liberal, democratic world led by the United States. Jeroen de Kloet, 
U T S

e PRE S S

Jian Lin, and Yiu Fai Chow (2020) similarly point out that the current pandemic has triggered a type of 'biopolitical nationalism' in East Asian societies-crystallised in the 'we are doing better' discourse in relation to COVID-19-with profound ideological implications. The current pandemic has exacerbated the rising nationalism that stifles cultural identities in East Asia and the world. How might we imagine alternatives? What types of critical and creative interventions are needed at this critical historical juncture?

In this article, I examine queer diasporic responses to the pandemic discourse by using queer filmmaker and artist Popo Fan's video Lerne Deutsch in meiner Küche (Learn German in My Kitchen) (2020a) as an example. I argue that the queer diasporic 'disidentification' that Fan uses in his artwork is an important critical intervention into the current pandemic discourse which prioritises identities and identifications. In his analysis of performances by queers of colour in the United States, José Esteban Muñoz (1999: 11) points out that disidentification is a mode of dealing with dominant ideology that 'neither opts to assimilate within such a narrative nor strictly opposes it' and that 'works on and against dominant ideology':

Instead of buckling under the pressures of dominant ideology (identification, assimilation) or attempting to break free of its inescapable sphere (counteridentification, utopianism), this 'working on and against' is a strategy that tries to transform a cultural logic from within, always labouring to enact permanent structural change while at the same time valuing the importance of local or everyday struggles of resistance. (11-12)

For Muñoz, disidentification is a useful tactic practised by minoritarian subjects such as queers of colour or members of the queer diaspora. The tactic of disidentification is attentive to both structural changes-by challenging racism, homophobia and heteronormativity — and everyday resistances which may be mundane, minute and even imperceptible. For minority queer subjects, because of their dual marginalisation in both a nation-state-dominated cultural narrative and in a mainstream discourse characterised by heterosexual reproductionism, their process of identification with dominant discourses is bound to be partial, incomplete, and even unsuccessful. Moments and instances of disidentification bespeak the minoritarian agency as well as the failure of the ideological interpellation and discursive closure.

As was the case with the last Cold War, the political and ideological affiliation of queer-identified people are under constant scrutiny in the current pandemic. Queer people from China are often forced to take a stance by making a choice between China and the Western world, and between a country where LGBTQ rights are not recognised and the part of the world where same-sex marriages have been legalised and gay people can be 'out and proud,' and between illiberal neoliberalism and liberal neoliberalism. This is an easier choice for some than others. As a queer-identified person born in the People's Republic of China and currently living in the UK, although I may have constantly felt the pressure to declare my own political and ideological allegiances, the new Cold War accompanying the global pandemic has only exacerbated the pressure.

Because I do not have an easy answer to this problem, I start to look around for examples to see how other queer people like myself are dealing with this issue. An example that strikes me is a short video made by the Berlin-based queer filmmaker Popo Fan. Originally from Beijing, Fan has lived in Berlin for several years to pursue a career as an artist and filmmaker. He was the first person to take China's censor, the State Administration of Radio, Film and Television, to court because of the latter's censorship of his film Mama Rainbow (Child 2015). Fan's current diasporic position was largely a personal choice: to go to a city where many artists gather and a city with unparalleled sexual freedom. Berlin was an obvious choice, although Fan constantly has to deal with issues such as language, bureaucracy and racism. Although anti-foreigner and anti-immigrant sentiments have always existed to some extent in large cosmopolitan cities like Berlin and behind the city's legendarily liberal facade, the current pandemic has not only made visible but also exacerbated Sinophobia and anti-Asian racism (DW 2020). The invisible enemy of the coronavirus has provided many people with a good excuse to discriminate against and vent their hatred against people of 
U T S

e PRES S
Chinese or Asian ancestry (Goll 2020). Fan has been verbally abused and even physically attacked at least twice in Berlin's public spaces. The most recent incident took place in March in a Berlin U-Bahn (subway) station where a young man shouted at him: 'Corona, du bist Corona. $\mathrm{F}^{* *} \mathrm{k}$ China, politische Diktatur' (Coronavirus, you are coronavirus. $\mathrm{F}^{* * \mathrm{k}}$ China, the political dictatorship) (Amir in Berlin 2020). Knowing that there was no use arguing back to such an unreasonable accusation that mistook an individual for a country, Fan took out his smart phone and recorded the incident. He subsequently took the video footage to the local police station to report it. The police registered the case. However, when Fan followed up the case a couple of weeks later, the police had done nothing and instead claimed that they could not find the CCTV footage on that day. Based on his previous experience of reporting similar hate crimes, Fan was familiar with this response. As an artist and filmmaker, he often uses his art to address social issues. He therefore made a video about his experience of being racially abused in the form of a comedy video.

The short video titled Lerne Deutsch in meiner Küche (Learn German in My Kitchen) was commissioned by RBB (Radio Berlin und Brandenburg) as part of the radio station's COVID-19 short video series '4 Wände Berlin: 30 Filme mit Abstand' (4 Walls Berlin: 30 Films with Distance). Fan's contribution to the series is a fun, YouTube-style video that resembles a DIY video combining cooking and language learning. With a duration of 2 minutes and 23 seconds, the video displays bilingual flashcards which divide the short video into several shorter sections. The words that appear in the video include: der Reis (米, the rice), die Karotte (胡夢卜, the carrot), die Fledermaus (蝙蝠, the bat), die Nudel (面, the noodle), der Virus (病毒, the virus). Each flashcard is followed by a German sentence with the word in it, emulating a language class. For example, the 'der Rice' (the rice) flashcard is exemplified by the sentence 'Ich hatte einen Reisbrei zum Frühstück' (I had rice porridge for breakfast). The video clip that illustrates this sentence shows Fan making rice porridge using a saucepan. Notably, most of the words displayed on the flashcards have an association with China or Asia. The bat, in particular, has become a potent and controversial symbol used by many to criticise Chinese for their grotesque dietary habits since the start of COVID-19 (Taylor 2020). These short video clips are linked by a cooking sequence, in which Fan demonstrates the process of making a Chinese-style noodle in his flat. Although most words (such as rice, carrots and noodle) on the flashcards are represented by real objects, some are not. For example, the 'bat' is demonstrated by several plastic bats used for Halloween decorations being thrown into a saucepan with boiling water as a reference for 'bat soup.' This sequence is accompanied by mysterious and ominous non-diegetic music often used in crime drama, intensifying its dramatic effect (the same sequence also appears at the beginning of the video to create suspense). The 'virus' flashcard is surprisingly followed by the video clip that Fan shot with his smart phone about his own experience of being racially abused in a Berlin U-Bahn station, suggesting that the real virus is racism. Resembling the style of a public interest advert, the video finishes with a line on the screen: 'Coronavirus unterscheidet nicht zwischen Nationalitäten. Und wir?' (Coronavirus does not make a distinction between nationalities. What about us?'), highlighting the video's anti-racism message.

Fan's video builds on, but at the same time challenges, Western stereotypes about China/Asia and Chinese/Asianness. Food such as rice and noodles are often associated with Chineseness and Asianness, and bats have recently been seen as the mythical origin of the pandemic in the global circulation of misinformation. In the video, Fan introduces one of his favourite foods, the reganmian (literally hot and dry noodle) from Wuhan. Here, in the midst of a global pandemic, the city of Wuhan is not referred to as a place of plague and misery, or a land of bat-eating oriental barbarity, but instead as a place that is home to a type of local delicacy with a human and personal touch. Following the 'bat' flashcard, Fan is shown in the video shaking his head and saying 'Nein ich habe noch nie Fledermaus gegessen' (No, I have never eaten a bat). This statement helps dispel the myth that all Chinese eat bats. But Fan's mode of address here is individuated. He is simply explaining that he has never eaten a bat himself and this does not preclude the possibility that someone else might have eaten a bat. By using an individualised mode of address, Fan also refuses to represent, and speak for, a group of people, such as the whole Chinese nation. For 
U T S

e P RES S

Fan, speaking for a group is a precarious act, as it can often create inclusions and exclusions. This belief is reflected in his wider work, especially in his queer community documentaries where he talks about queer family relationships without making a statement about a universalised 'Chinese queer' experience. An individualised mode of address, in this context, challenges both the Western accusation of the Chinese as a bat-eating and barbaric nation, as well as the middle-class Chinese collective denial of a possibly minoritarian dietary practice, demarcating the world along the primitive/civilised line.

Fan is an 'out' queer person. This video is in fact one of his rare non-explicitly-queer works. But the queer element is also embedded in the video. The whole video is autographic in nature and is characterised by a dramatic 'camp' style, which is an important aspect of queerness. In the opening sequence of the video, Fan takes out a carrot from behind his back, grabbing the carrot with his hand as if he is holding a sex toy, and shouts ' $\mathrm{f}$ "* $\mathrm{k}$ ' when he attempts to catch a falling object. This sequence is followed by the flashcard for 'rice.' In English queer slang, rice is usually associated with Asian gay men. For example, a 'rice queen' is someone (usually a Caucasian gay man) who is sexually attracted to Asian men; and the slang 'sticky rice' refers to Asian gay men attracted to each other (Caluya 2008). Fan's cooking sequence taps into the stereotype of a domestic - and perhaps slightly effeminate and desexualised-Asian gay man in the Western gay scene. But Fan also challenges such a stereotype by refusing to play a quiet and docile role. The fact that he speaks German, makes videos, and even uses the video footage of his own experience of being racially abused to make social commentary about racism, disrupts the stereotype of a quiet and submissive Asian male image. When I interviewed him on why he made this video, Fan replied:

I would like to show to others what I do and what I eat at home, and I hope this can disrupt some confusions about and stereotypes of Asians. Food is a particularly important element in my life. It is also a reason why many Asians, and especially Chinese, are stigmatised in the world. This video shows what Asians really eat in a joking way. It functions as a form of self-irony and sarcasm.

Humour, irony, and sarcasm - these are the tools that Fan uses to critique racism and Sinophobia. As Muñoz (1999: xi) points out, humour is a valuable pedagogical and political tool for queer minoritarian subjects; through humour, queer performers of colour find strength and solidarity in subverting the assumed seriousness of the dominant discourse. Rather than being passive and pessimistic about the situation, Fan adopts a more proactive and even activist approach to intervene in the current global pandemic discourse. Apart from making videos, Fan (2020b) also writes articles about his intimate life, reflecting on the transformation of queer intimacy in the current pandemic and satirising the queer-unfriendly, home-andcoupledom-centred, and heteronormative quarantine measures. He also leads virtual tours, showing aspects of queer Asian life in Berlin (Fan 2020c). These function as forms of creative and critical interventions-and indeed, a queer Asian political intervention-in the current debate about the pandemic.

Perhaps most important of all, Fan identifies with being neither Chinese nor German, neither with a political dictatorship nor a liberal democracy—he disavows these deeply embedded political and ideological positions reinforced by the new Cold War accompanying COVID-19. He turns instead to food, something to which people can relate to wherever they come from and whichever political camp they side with. This mundane reference to everyday life functions as a critique of fixed identities and entrenched political divisions, and a recognition of the messiness of everyday life that defies definition (Probyn 2000). As part of a queer diaspora living in Berlin, Fan refuses to make national identifications. He prefers turning to the regional cultural imaginary of being Asian, together with his queer politics, for self-identificationbeing both Asian and queer. The closing message of the video: 'Coronavirus unterscheidet nicht zwischen Nationalitäten. Und wir?' (Coronavirus does not make a distinction between nationalities. What about us?) nicely sums up this political stance.

At a historical moment marked by growing antagonisms based on rigid lines of nation states, group interests, politics, and ideologies, how do queer people—especially queer people of colour living in the 
U T S

e PRE S S

diaspora - position themselves? For queer scholars, activists and artists of Chinese origin or working in Chinese-language contexts, there has been an increasing demand for them to choose between contrasting alliances and affiliations, including 'queer Chinese,' 'queer Sinophone,' 'queer Asian,' 'queer diaspora,' queer transnational,' 'queer international,' among others. Each term embodies a series of institutional affiliations, group solidarity and citational politics. These efforts of demarcating territories are often premised on an identity politics against which queer theory has a tradition of fighting. They are mostly built upon a belief in an essentialised and unchanging nature of identity, as well as the exclusivity of such an identity: 'either A or B.' How about thinking of political and ideological positions in terms of 'neither A nor B,' or 'both $\mathrm{A}$ and B,' or 'beside A and B.'These fluid positionalities aptly recognise the messiness of human lives and their experiences, along with the multiple, fleeting, and contingent nature of social identities in real life. A living theory and a vital mode of political practice must be able to account for the complexity, richness and contingency of people's identifications, experiences and affects.

José Esteban Muñoz's (1999) notion of 'disidentification' is therefore useful here: instead of trying to identify with fixed identities and political positions, minority groups can also develop partial, incomplete, conditional, fleeting, contingent and constantly shifting identification with subject positions and politics. Indeed, in the midst of a global pandemic and in the shadows of a resurging Cold War, instead of asking what we identify with, perhaps we should also ask what we disidentify with, and why. Queer disidentification is therefore a much-needed political position in the context of a global pandemic.

\section{References}

Amir in Berlin. 2020, 'Berlin Talks 01: Popo Fan.'YouTube. Online, available: https://www.youtube.com/ watch?v=DQZKNrRK go\&feature=youtu.be\&fbclid=IwAR3TGkuu98s]B9GUA0Cu 7Xr-8fL6Un5FQCuoUGws7wIqM6wm IK-4VPDU [Accessed 25 May 2020].

Caluya, G. 2008, “'The Rice Steamer”: Race, Desire and Affect in Sydney’s Gay Scene,' Australian Geographer, vol. 39, no. 3: 283-292. https://doi.org/10.1080/00049180802270481

Child, B. 2015, 'Film-Maker Sues Chinese Censors Over “Ban” on Gay-Themed Movie,' The Guardian, 24 September. Online, available: https:/www.theguardian.com/film/2015/sep/24/mama-rainbow-film-maker-sues-chinese-censorsover-ban-on-gay-themed-movie [Accessed 25 May 2020].

de Kloet, J., Jian L., \& Chow, Y. F. 2020, 'We Are Doing Better': Biopolitical Nationalism and the COVID-19 Virus in East Asia,' European Journal of Cultural Studies, vol. 23, no. 4: 635-640. https://doi.org/10.1177/1367549420928092

DW. 2020, 'Der Tag vom 07.05.2020.' Deutsche Welle. Online, available: https://www.dw.com/de/der-tagvom-07052020/av-53366236?maca=de-Facebook-sharing\&fbclid=IwAR0P396aaIerAa5sRME6z8fpLP981yumI Wi_Mpy9g9kn0ko9N4iIEyTbiOw [Accessed 25 May 2020].

GCS Sydney. 2020, 'Intimacies in Asia in a Time of Pandemics.'YouTube. Online, available: https://www.youtube.com/ watch?v=hpSTLCw1etU [Accessed 25 May 2020].

Fan, P. dir. 2020a, Lerne Deutsch in meiner Küche (Learn German in My Kitchen). Online, available: https://www. rbb-online.de/derrbbmachts/kurzvideo/videos/der-rbb-macht-kurzfim-lerne-deutsch-in-meiner-kueche-popo-fan.html [Accessed 25 May 2020].

Fan, P. 2020b, 'Hooking Up Under Lockdown.' Trans. Allen Young, Los Angeles Review of Books: China Channel, 8 May. Online, available: https://chinachannel.org/2020/05/08/COVID-hookup/?fbclid=IwAR0Wf1t0Ba51JP21s9fn1qCfSjG 33mDiplYPnVZv014Z-i7fnOXsAys2SFA [Accessed 25 May 2020]. 
Fan, P. 2020c, 'Ein ineastischer Nachtspaziergang mit Fan Popo.' Digital Kulturama, 31 May. Online, available: https:// kulturama.goethe.de/event/ein-cineastischer-nachtspaziergang-mit-fan-popo-888?fbclid=IwAR2WN86yu9jxI UyfOQWlt9RIM6POIXljcN5ZtEs86FyPvPKRvQqVWSD-K4 [accessed 25 May 2020].

Goll, J. 2020, 'Dich sollte man mit Sagrotan einsprühen.’ RBB 24, 24 April. Online, available: https://www.rbb24.de/ politik/thema/2020/coronavirus/beitraege neu/2020/04/rassismus-asiatisches-aussehen-berlin-attacken-beleidigungen. html?fbclid=IwAR2xVhTFccCEeXiDRXgkn0hF-la-rtm6rmnLlUqklgkWBxL9e5xA9xIFeZY [Accessed 25 May 2020].

Muñoz, J. E. 1999, Disidentifications: Queers of Colour and the Performance of Politics. Minneapolis, MN, University of Minnesota Press.

Probyn, E. 2000, Carnal Appetites: FoodSexIdentities. London, Routledge.

Taylor, J. 2020, 'Bat Soup, Dodgy Cures and “Diseasology”: The Spread of Coronavirus Misinformation,' The Guardian, 31 January. Online, available: https:/www.theguardian.com/world/2020/jan/31/bat-soup-dodgy-cures-and-diseasologythe-spread-of-coronavirus-bunkum [Accessed 25 May 2020]. 